\title{
Diabetic Foot Disease Research in Aotearoa New Zealand: A Bibliometric Analysis (1970-2020)
}

Matthew Carroll ( $\square$ matthew.carroll@aut.ac.nz )

Auckland University of Technology https://orcid.org/0000-0001-5095-0539

Ibrahim Saleh Al-Busaidi

University of Otago Christchurch

Kirsten J Coppell

University of Otago Dunedin School of Medicine

Michele Garrett

Auckland District Health Board

\section{Belinda Ihaka}

Auckland University of Technology

Claire O'Shea

Waikato District Health Board

Justina Wu

Waikato District Health Board

Steve York

Northland District Health Board

\section{Research}

Keywords: Bibliometric analysis, Diabetic foot disease, Diabetes mellitus, Diabetic foot, Research, Aotearoa New Zealand

Posted Date: November 1st, 2021

DOI: https://doi.org/10.21203/rs.3.rs-1021707/v1

License: (a) This work is licensed under a Creative Commons Attribution 4.0 International License. Read Full License 


\section{Abstract}

\section{Aim}

The aim of this bibliometric study was to examine trends in the quality and quantity of published diabetic foot disease (DFD) research in Aotearoa/New Zealand (NZ) over the past five decades.

\section{Method}

In July 2021, the Scopus ${ }^{\circledR}$ database was searched for DFD-related publications (1970-2020) using predetermined search and inclusion criteria. Bibliometric data were extracted from Scopus ${ }^{\circledR}$ and Journal Citation Reports. Retrieved bibliographic indicators were analysed in Biblioshiny, an R Statistical Software interface and reported using descriptive statistics.

\section{Results}

Forty-seven DFD-related articles were identified. The annual number of publications showed a significant upward trend increasing from one in 1988 to 47 in $2020(P<0.001)$. The majority of identified articles $(n=31$, $66 \%)$ were published in the last decade (2011-2020). Basic/clinical research accounted for $87 \%(n=41)$ of publications and $14(30 \%)$ investigated the screening and/or prevention of DFD. The average citation per article was 20.23 (range: 0-209) and the median impact factor was 4.31 (range, 1.82-79.32). Over a third of articles (36\%) had an international authorship network. Funding was reported by 15 (32\%) articles; $12(26 \%)$ were supported by public national grants vs. three $(6 \%)$ reporting industry-sponsorship.

\section{Conclusion}

DFD articles authored by NZ researchers have increased over the past five decades. Despite that NZ researchers increased their global impact through collaborative networks, most of the research was classified as low-level evidence, with limited focus on Indigenous Māori and limited financial support and funding. Increased funding for interventional research is required to enable a higher level of evidence-based and practice-changing research to occur. With rates of diabetes related amputations higher in Māori future research must focus on reducing inequalities in diabetes related outcomes for Māori by specifically targeting the prevention and screening of DFD in primary care settings in NZ.

\section{Introduction}

Diabetic foot disease (DFD) is one of the most devastating, but potentially avoidable complications of diabetes $(1,2)$. DFD is defined as a foot affected by infection, ulceration or destruction of tissues of the foot of a person with currently or previously diagnosed diabetes mellitus, usually accompanied by neuropathy and/or PAD in the lower extremity (3). Diabetic foot ulcers are the most frequently recognised complication of DFD and a major risk factor for, and nearly always precede, diabetes-related lower-extremity amputation (DRLEA) (4-6). DRLEA is one of the most substantial and debilitating consequences of diabetes (7). 
In Aotearoa/New Zealand (NZ), diabetes is common. In 2008/09, the prevalence of diabetes (diagnosed and previously undiagnosed) among those aged $\geq 15$ years was $7.0 \%$ overall, and ethnic specific rates were $9.8 \%$, 15.4\% and 6.1\% among Māori, Pacific peoples and non-Māori non-Pacific peoples, respectively (8). More than half (58\%) of DRLEAs are attributable to diabetes (9) and Indigenous Māori people are more likely to experience DRLEA than their NZ European counterparts (10). Gurney et al. demonstrated that Māori with diabetes were $65 \%$ more likely to undergo major DRLEA than NZ European/Other people with diabetes (9). Understanding DFD research quantity and quality in the NZ context is important, as Indigenous Māori people not only have high rates of DRLEA $(10,11)$, but also fare worse in many other diabetes-related health measures $(11,12)$.

Whilst the understanding of DFD has been advanced over many decades based on international research, the contribution of locally NZ driven DFD-related research appears to be limited (10-12). Consequently, we do not know if NZ based DFD-related research is strategically targeting areas where research need is the greatest in order to reduce diabetes-related DRLEA and improve health outcomes. The objective of this study was to provide the first comprehensive bibliometric analysis of DFD-related research generated by NZ based researchers. Specifically, the study aimed to identify underlying patterns in DFD publications, author-specific contributions, the volume of scholarly work overtime, the degree of national and international collaborations, and the major topics/areas of research focus.

\section{Methods}

\section{Data source}

This bibliometric analysis of NZ DFD-related publications between 1970 and June 2021 was conducted in July 2021 using data sourced from the Scopus ${ }^{\circledR}$ database (Elsevier, Amsterdam, Netherlands). The Scopus ${ }^{\circledR}$ database was selected as it enables search by document, author or affiliation, or use, with the ability to refine results by author and publication characteristics. It has the largest abstract and citation database of research literature (13). As of January 2020, Scopus ${ }^{\circledR}$ had in excess of 25,100 active titles and over 550 articles in press (14). Additionally, Scopus ${ }^{\circledR}$ includes a more expanded spectrum of journals than PubMed and Web of Science ${ }^{\circledR}$, and its citation analysis is faster and includes more articles than the citation analysis of Web of Science ${ }^{\circledR}$ (15).

\section{Search strategy}

The search strategy was developed through a staged process, involving adaptation of a search strategy used in a previous bibliometric analysis of DFD conducted by some of the authors of this study (16). Initially, AlBusaidi et al.'s search strategy was run in Scopus ${ }^{\circledR}(16)$, with the 15 most cited articles retrieved. Author keywords, Medical Subject Headings (MeSH) classifications, and Emtree (Embase subject headings) terms were then downloaded from Scopus ${ }^{\circledR}$ and exported into NVivo Qualitative Data Analysis Software (QSR International Pty Ltd. Version 12, 2018) and analysed by text query analysis to obtain word frequency counts. Keywords were reviewed and discussed by the authors to develop the final search strategy displayed in Table 1. 
Table 1

Scopus ${ }^{\circledR}$ search strategy $(1970-2020)$

\begin{tabular}{|l|}
\hline Keywords \\
\hline 1. Diabet* \\
\hline 2. Neuropathy \\
\hline 3. Arterial \\
\hline 4. Amputation \\
\hline 5. Infect* \\
\hline 6. Ulcer \\
\hline 7. Wound \\
\hline 8. Foot or feet \\
\hline Search strategy \\
\hline 1 AND 2 OR 3 OR 4 OR 5 OR 6 OR 7 OR 8 \\
\hline Search restrictions \\
\hline Year \\
\hline Language
\end{tabular}

\section{Data processing}

The titles and abstracts of all identified publications were downloaded from Scopus ${ }^{\circledR}$ database and exported into the online systematic review application Rayyan (http://rayyan.qcri.org) (17). The articles were then independently screened by two authors (MC, ISA) and selected based upon pre-determined inclusion and exclusion criteria agreed by all authors (Box 1). Conflicts arising from the screening process were resolved via a consensus meeting. A third author (KC) was available if screening conflicts were not resolved at an initial meeting, but this was not required. The reference lists of the final included articles were also scanned to find any additional publications. The study retrieval process is displayed in Figure 1.

Box 1 Inclusion and exclusion criteria 
Inclusion criteria

Publications were included if:

1. They were original articles, or systematic reviews with meta-analysis; and

2. The research was conducted within an NZ institution; and

3. Data were reported that was conducted on an NZ population; and

4. The article had at least one author with an affiliation to an NZ research institution; and

5. They were published in English, and

6. The field of research was related to DFD (including screening, prevention, diagnosis, management, complications, and workforce) and relevant conditions (peripheral neuropathy, neuroarthropathy, peripheral artery disease, infections, deformity, ulceration, and amputation); and

7. They were published between 1970 to the current date (date of search)

Exclusion criteria

The following studies were excluded: non-original research publications, non-systematic reviews, case reports, commentaries, letters, and editorials

DFD: diabetic foot disease; NZ: Aotearoa New Zealand.

The following data and bibliometric indicators were extracted from each publication: title, year of publication, journal name, journal impact factor (IF), citation count, author names, total authors per manuscript, institutional affiliation, collaboration network and funding source. Collaborative networks were classified into four categories: (1) "international collaborative" articles involving collaboration with international authors, (2) "bi-national link" articles originating from authors affiliated to only two NZ institutions, (3) "multi-national link" articles authored by researcher from three or more NZ institutions, and (4) "no collaboration" articles representing publications where all authors were affiliated to the same institution $(16,18)$. Funding sources were classified into two categories: (1) industry sponsored funding, and (2) academic/public funding (funding derived from universities, hospitals, or government bodies). Using the 2019 IWGDF guidelines as guidance, articles were classified into the following predetermined categories; (1) screening and prevention of DFD, (2) management of DFD related conditions, (3) epidemiology, and (4) other/miscellaneous (publications that did not fit into one of the above groups) (19). Articles were also characterised by type of study (basic/clinical research articles, systematic review with meta-analyses, and randomised controlled trials (RCT)) (20).

As a measure of research quality, the journal IF attained in the year prior to publication was obtained using the Web of Science Journal Citation Reports ${ }^{\mathrm{TM}}$ tool (Clarivate Analytics, Philadelphia, Pennsylvania, USA). The number of citations per article was determined using the Scopus ${ }^{\circledR}$ database (Elsevier). All data were extracted into a custom Microsoft Excel spreadsheet, Version 2016 (Microsoft Corp., Redmond, Washington, USA) and also into the Biblioshiny software for additional analysis (based on $\mathrm{R}$ version 3.6.1, Bibliometrix package version 2.2.1; University of Naples Federico II, Naples, Italy, 2016) (21). Biblioshiny was used to extract the following data: general characteristics of the included articles, annual scientific production, average citations per year, and most relevant authors, and collaboration world map. The nonparametric Mann-Kendall test was 
applied to data to detect statistically significant trends in publication numbers and collaborative networks. Statistical significance was determined as $\mathrm{p}$-value $(<0.05)$.

\section{Results}

The characteristics of the included studies are displayed in Table 2. A total of 140,489 publications were initially identified of which 444 articles satisfied the inclusion criteria (Figure 1). After application of the exclusion criteria 47 articles were included in the final analysis.

Table 2

Characteristics of the included studies $(n=47)$

\begin{tabular}{|ll|}
\hline Variable & Number \\
\hline Total number of articles & 47 \\
\hline Average years from publication & 9.62 \\
\hline Average citations per article & 20.23 \\
\hline Average citations per year per article & 2.56 \\
\hline References & 1266 \\
\hline Total authors (range: 2-18) & 300 \\
\hline Average co-authors per article & 6.38 \\
\hline Unique authors (mean 4.81) & 226 \\
\hline Single-authored articles & 0 \\
\hline
\end{tabular}

\section{Volume of scientific production}

The volume of NZ-produced DFD publications has steadily increased since 1988 with an annual compound growth rate of $5.4 \%$. The number of publications per year showed a statistically significant positive trend $\left(\tau_{b}=\right.$ $0.66, \mathrm{P}<0.001)$ increasing from one in 1988 to 47 in 2020 (Figure 2). The majority of articles $(n=31,66 \%)$ were published in the last decade (2011-2020). The most articles published in one year was six in 2018 with representing $13 \%$ of total publications. Of the 47 articles, the majority ( $87 \%$ ) were focused on basic/clinical research, with six (13\%) RCTs. No systematic reviews with meta-analysis were identified.

\section{Areas of research focus}

When categorised by area of research, 14 (30\%) investigated screening or prevention of DFD, 15 (32\%) management of diabetes-related foot complications, 16 (34\%) the epidemiology of DFD, and two studies (4\%) investigated other aspects of DFD (the financial burden of DFD care in hospital settings and vasoconstrictive responses in the skin). 
Fifteen articles (32\%) reported receiving funding support. Eleven articles (23\%) reported receiving NZ based funding. Of these, $10(21 \%)$ were funded through university/public sources, with one industry funded. Four (9\%) international multicentre studies reported funding from international sources.

\section{Author and authorship network}

Authorship networks for articles published between 1988 and 2020 are displayed in Figure 3. No studies were single authored. Articles had a median of five co-authors per article (range: 2 -18). Seventeen (36\%) of the included articles had an international authorship link with a "bi-national link" in ten articles (21\%), a "multinational link" in six articles (13\%), and "no collaborative link" outside of one institution in 14 articles (30\%). There was a significant increasing trend of international collaboration $\left(\tau_{b}=0.47, P=0.008\right)$ between 1988 and 2020 but no significant trend found in bi-national author collaboration $\left(\tau_{b}=-0.035, P=0.87\right)$ during the same time. Of the 39 articles published between 2006 and 2020 there were international links identified in 16 articles $(41 \%)$ and bi-national links in 10 articles (26\%). Of the 10 articles with bi-national links, eight (80\%) were networks between universities and District Health Boards (DHB). A total of eight articles were published between 1986 and 2005, six of which had no collaborative links. The most frequent international authorship links occurred between NZ and Australia (12 articles), Finland ( 6 articles) and Germany ( 6 articles). A world map displaying international collaborative research links by country is displayed in Figure 4 .

\section{Most common journals}

The identified 47 articles were published in 27 different journals of which the New Zealand Medical Journal ( $n$ $=10,21 \%)$ and Diabetes Research and Clinical Practice $(n=4,8 \%)$ were the most common. There were 18 journals (38\%) where only one of these DFD-related articles was published. The journals that published two or more publications accounted for $63 \%$ of all identified articles (Table 3 ).

Table 3 Frequency of publication of the most common journals that have published two or more Aotearoa New Zealand diabetic foot related research articles

\begin{tabular}{ll} 
Journal & $\mathbf{n}(\%)$ \\
\hline New Zealand Medical Journal & $10(21)$ \\
\hline Diabetes Research and Clinical Practice & $4(9)$ \\
\hline Diabetologia & $3(6)$ \\
\hline Primary Care Diabetes & $3(6)$ \\
\hline Diabetes Care & $2(4)$ \\
\hline Gait and Posture & $2(4)$ \\
\hline Journal of Foot and Ankle Research & $2(4)$ \\
\hline Journal of Vascular Surgery & $2(4)$
\end{tabular}




\section{Quality appraisal (impact factor and citations)}

IF was available for 34 (72\%) of the journals where the included NZ based research articles were published.

The median IF for the included studies was 4.31 (IQR: 2.75-6.81, range 1.82-79.32). The articles had a total of 951 citations, with an average citation of 20.2 per article (median: 10, IQR: 4-24, range: 0-209 citations). Three (6\%) articles were cited once and two articles (3\%) received no citations. The Lancet (209 citations) and Diabetes Care (98 citations) contained the most citations from NZ DFD based research.

\section{Five most cited articles}

The top five source journals are displayed in Table 4. The most cited article was published by Rajamani et al (22) in The Lancet in 2009 (209 citations). This article represented $22 \%$ of the total citations for all included articles. The five most cited articles represented $46 \%$ of the total citations. Four of the most cited articles were international multicentre RCTs. Only one of the five most cited studies had a NZ researcher as first author (23). With the exception of Behrendt et al's observational study (24), all studies were supported by funding.

Table 4 Five most cited diabetic foot disease-related publications (1988-2020) 


\begin{tabular}{|c|c|c|c|c|c|c|}
\hline $\begin{array}{l}\text { Author and } \\
\text { Publication }\end{array}$ & $\begin{array}{l}\text { First } \\
\text { author } \\
\text { country } \\
\text { affiliation }\end{array}$ & Publication title & Journal & $\begin{array}{l}\text { Number } \\
\text { of } \\
\text { citations }\end{array}$ & $\begin{array}{l}\text { Total } \\
\text { citations } \\
\text { per year }\end{array}$ & $\begin{array}{l}\text { Funding } \\
\text { source }\end{array}$ \\
\hline $\begin{array}{l}\text { Rajamani } \\
\text { et al.(22) }\end{array}$ & Australia & $\begin{array}{l}\text { Effect of fenofibrate } \\
\text { on amputation events } \\
\text { in people with type } 2 \\
\text { diabetes mellitus } \\
\text { (FIELD study): a } \\
\text { prespecified analysis } \\
\text { of a randomised } \\
\text { controlled trial }\end{array}$ & The Lancet & 209 & 16.08 & International \\
\hline $\begin{array}{l}\text { Herrman et } \\
\text { al.(33) }\end{array}$ & Australia & $\begin{array}{l}\text { Serum 25- } \\
\text { Hydroxyvitamin D: A } \\
\text { predictor of } \\
\text { macrovascular and } \\
\text { microvascular } \\
\text { complications in } \\
\text { patients with type } 2 \\
\text { diabetes }\end{array}$ & Diabetes Care & 86 & 12.28 & International \\
\hline $\begin{array}{l}\text { Behrendt et } \\
\text { al.(24) }\end{array}$ & Germany & $\begin{array}{l}\text { International } \\
\text { Variations in } \\
\text { Amputation Practice: } \\
\text { A VASCUNET Report }\end{array}$ & $\begin{array}{l}\text { European } \\
\text { Journal of } \\
\text { Vascular and } \\
\text { Endovascular } \\
\text { Surgery }\end{array}$ & 50 & 12.50 & $\begin{array}{l}\text { No funding } \\
\text { declared }\end{array}$ \\
\hline $\begin{array}{l}\text { Chan et al. } \\
\text { (34) }\end{array}$ & Australia & $\begin{array}{l}\text { Plasma total bilirubin } \\
\text { levels predict } \\
\text { amputation events in } \\
\text { type } 2 \text { diabetes } \\
\text { mellitus: The } \\
\text { Fenofibrate } \\
\text { Intervention and } \\
\text { Event Lowering in } \\
\text { Diabetes (FIELD) } \\
\text { study }\end{array}$ & Diabetologia & 49 & 5.44 & International \\
\hline $\begin{array}{l}\text { Dobson et } \\
\text { al.(23) }\end{array}$ & NZ & $\begin{array}{l}\text { Effectiveness of text } \\
\text { message based, } \\
\text { diabetes self- } \\
\text { management support } \\
\text { programme } \\
\text { (SMS4BG): Two arm, } \\
\text { parallel randomised } \\
\text { controlled trial }\end{array}$ & $\begin{array}{l}\text { British } \\
\text { Medical } \\
\text { Journal }\end{array}$ & 46 & 11.50 & NZ \\
\hline
\end{tabular}

Table 5 details the most cited articles where an author from NZ was the first author. With the exception of Dobson et al. (23), all were observational studies based in NZ $(12,23,25)$. Three studies declared funding from an academic/public source withing NZ while two studies were not supported financially $(26,27)$.

Table 5 Most cited diabetic foot disease-related publications with Aotearoa New Zealand researcher as a primary author cited between 1988-2020 


\begin{tabular}{|c|c|c|c|c|c|}
\hline $\begin{array}{l}\text { Author and } \\
\text { Publication }\end{array}$ & Publication title & Journal & $\begin{array}{l}\text { Number } \\
\text { of } \\
\text { citations }\end{array}$ & $\begin{array}{l}\text { Total } \\
\text { citations } \\
\text { per year }\end{array}$ & Funding \\
\hline $\begin{array}{l}\text { Dobson et } \\
\text { al.(23) }\end{array}$ & $\begin{array}{l}\text { Effectiveness of text message } \\
\text { based, diabetes self- } \\
\text { management support } \\
\text { programme (SMS4BG): Two } \\
\text { arm, parallel randomised } \\
\text { controlled trial }\end{array}$ & $\begin{array}{l}\text { British } \\
\text { Medical } \\
\text { Journal }\end{array}$ & 46 & 11.50 & $\begin{array}{l}\text { Academic/public } \\
\text { from } \\
\text { NZ source }\end{array}$ \\
\hline $\begin{array}{l}\text { Nukada et } \\
\text { al.(25) }\end{array}$ & $\begin{array}{l}\text { Pathology of acute and chronic } \\
\text { ischaemic neuropathy in } \\
\text { atherosclerotic peripheral } \\
\text { vascular disease }\end{array}$ & The Brain & 44 & 1.69 & $\begin{array}{l}\text { Academic/public } \\
\text { from } \\
\text { NZ source }\end{array}$ \\
\hline $\begin{array}{l}\text { Bevan \& } \\
\text { Tomlinson } \\
(26)\end{array}$ & $\begin{array}{l}\text { Radiographic measures as a } \\
\text { predictor of ulcer formation in } \\
\text { diabetic Charcot midfoot }\end{array}$ & $\begin{array}{l}\text { Foot \& Ankle } \\
\text { International }\end{array}$ & 41 & 2.92 & $\begin{array}{l}\text { No funding } \\
\text { declared }\end{array}$ \\
\hline $\begin{array}{l}\text { Misra et al. } \\
\text { (27) }\end{array}$ & $\begin{array}{l}\text { Peripheral neuropathy and tear } \\
\text { film dysfunction in type } 1 \\
\text { diabetes mellitus }\end{array}$ & $\begin{array}{l}\text { Journal of } \\
\text { Diabetes } \\
\text { Research }\end{array}$ & 40 & 5.0 & $\begin{array}{l}\text { No funding } \\
\text { declared }\end{array}$ \\
\hline $\begin{array}{l}\text { Gurney et } \\
\text { al.(12) }\end{array}$ & $\begin{array}{l}\text { Risk of lower limb amputation } \\
\text { in a national prevalent cohort } \\
\text { of patients with diabetes }\end{array}$ & Diabetologia & 29 & 7.25 & $\begin{array}{l}\text { Academic/public } \\
\text { from } \\
\text { NZ source }\end{array}$ \\
\hline
\end{tabular}

\section{Discussion}

Bibliometric analyses are useful for providing an overview of published literature, identifying knowledge gaps, uncovering emerging trends, and deriving novel ideas for future investigation (28). The present study analysed the research quantity (i.e., publication output, areas of research focus and trends over time) and quality (i.e., the level of evidence, degree of collaboration, impact factor and citation rates) of NZ DFD-related research.

Whilst the number of articles is relatively small, between 1988 and 2020, the number of NZ produced DFD publications has steadily increased. Notably from 2006 onwards there was an increase in published articles with a peak of six new articles in 2018, and an increase in research growth and national collaboration. The underlining reasons for the increase in DFD research are not attributable to any one factor but may be resultant from numerous diabetes quality of care strategies, policies and initiatives implemented in the early 2000s in NZ. Additional File 1 presents a timeline of policies/strategies/initiatives that may have potentially influenced NZ DFD research. Notably during this period, the NZ Government strategy elevated the importance of diabetes with the release of The NZ Health Strategy (2001) (29). Reducing the incidence and impact of diabetes was one of the 13 health objectives chosen for implementation in the short to medium term.

Whilst the significance of diabetes in context of NZ came to the fore with changes in health policy and strategy, research development prior to 2000 was hindered by limited research funding. In 2000 , health research accounted for only $1 \%$ of the national health budget (30). It was not until 2005 that the Health 
Research Council (HRC) of NZ became a Crown agent, charged with putting into effect government policy in relation to health research. The opportunities for NZ researchers to obtain funding has improved in the past 15 years, however our results indicate DFD research by NZ researchers is still poorly funded with only $32 \%$ of the included articles declaring research funding support. Most of these studies were funded by national organisations (DHBs, universities, HRC; $n=11,23 \%$ ) and represent studies that were largely observational in nature. Consequently, as these types of studies are of a lower level of evidence, they are often insufficient to change clinical practice in comparison to large international multicentre and randomised studies funded through multiple international sources. Without significant investment, resourcing to implement high level of evidence locally relevant studies such as RCTs will remain limited.

The research collaboration post 2006 demonstrated marked growth with international and bi-national collaboration increasing. Bi-national authorship post 2006 may have been positively affected by increasing working relationships between DHBs, Primary Health Organisations (PHOs), and university research institutes, partially facilitated by health system restructures. Our data shows there has been a high level of bi-national collaboration since 2006 with $80 \%$ of national collaboration occurring between a DHB and university research institute/department. International collaborations are also indicative of the increasing global reach of NZ based research and active exchange of knowledge and research skills.

Despite the increase in number of publications and increased national and international collaborations, the majority of the identified publications (87\%) represent studies classified as basic/clinical research, which represents a lower level of evidence as per the Oxford Centre for Evidence-based Medicine (level 3 or 4 evidence) (31). Based upon the Oxford levels of evidence rating, and the relatively low citations rates, the majority of the identified NZ DFD-related publications were categorised as of poor quality. Of the top five cited articles (contributing $46 \%$ of total citations), four were RCTs (one first-authored by NZ researcher) and four were multicentre studies first-authored and led by international researchers. The most cited articles are either multicentre national or international RCTs representing high quality of evidence.

The median journal IF (4.31, IQR: 2.75-6.81) was relatively low for included publications. Only five articles were published in journals with an IF of greater than 10. Of note, most publications were published in the New Zealand Medical Journal ( $n=10,21 \%)$, which does not currently hold an IF. IF is the most common metric for evaluating bibliometric impact of published research, however the value of the research is not necessarily reflected by the IF (16). This finding is interesting as researchers often seek publication in so called higher impact/prestigious journals with the intention of improving their personal citation rate, and h-indices.

Furthermore, academic staff promotions at universities often depends upon the publication of a certain number of articles in scientific journals (32). However, authors sometimes chose to publish in journals based on the intended audience/readership where the article may have the most context and/or clinical impact. This may be more common when authors come from a clinical rather than purely academic background, where their driver maybe to improve outcomes rather than produce high ranked research outputs. Alternatively, the decision to publish in a particular journal may be dictated by the availability of funding to support the fees associated with publication. A combination of the above factors may be likely reasons for many NZ authored DFD articles being published in the New Zealand Medical Journal. 
Categorisation of research by type found that there was a relatively even spread number of articles categorised as screening/prevention, management of diabetes-related foot complications, and epidemiological studies. However, of the studies categorised as screening/prevention none were interventional studies. With few studies aimed at improved care or prevention of diabetic foot ulceration/amputation, coupled with recent international calls to reduce foot ulcer incidence by at least $75 \%$ and local NZ health priorities to reduce health inequities for Māori, a shift in DFD research priorities is essential (6). Therefore, the first steps towards this goal are to evaluate the performance of diabetic foot services aimed at prevention and early detection of DFD, and the ability of services to reduce inequities in access to services and health outcomes. This is a priority in NZ given the regional variation in DRLEA and significantly higher amputation rates for Māori $(7,9,10)$.

The results of this study have several limitations that must be considered. All metrics were extracted based upon our pre-defined search terms, and data only from the Scopus ${ }^{\circledR}$ database, which may not include all publications that meet our inclusion criteria. Some peer-reviewed journals are not indexed in Scopus ${ }^{\circledR}$. However, we also checked for additional publications by screening reference lists of identified articles from the initial search. As this study included only journal articles, our findings may not reflect all NZ DFD literature. It is acknowledged there may be gray literature sources that reveal a number of NZ based quality-of-care improvement initiatives related to DFD that are not published in peer reviewed journals. Finally, citation analysis and journal IF were used as markers of research quality and impact, which are vigorously debated as research quality indicators (16).

\section{Conclusion}

DFD articles authored by NZ researchers have increased over the past five decades. Despite NZ researchers increasing their global impact through collaborative networks, most of the research was classified as low-level evidence, with limited financial support and funding. Increased funding for interventional research is required to enable a higher level of NZ relevant, evidence-based and practice-changing research to occur. Future research must focus on reducing inequalities in diabetes-related outcomes for Māori by specifically targeting the prevention, screening and management of DFD in NZ.

\section{List Of Abbreviations}

NZ: Aotearoa New Zealand

DFD: Diabetic foot disease

DHB: District Health Board

IF: Impact factor

DRLEA: Diabetes-related lower-extremity amputation

PHO: Primary health organisations

RCT: Randomised controlled trial 


\section{Declarations}

\section{Ethics approval}

Due to the nature of a bibliometric analysis, no ethical considerations were required.

\section{Consent for publication}

Not applicable.

\section{Availability of data and material}

All data used in this article can be found on the Scopus database using the search strategy outlined in the Methods section. A complete list of all included papers in available upon reasonable request from the corresponding author.

\section{Author contributions}

All authors designed the study. MC and ISA collected, screened, and analysed all data. MC and ISA drafted the manuscript. All authors reviewed subsequent manuscript draft versions. All authors read and approved the final manuscript prior to submission.

\section{Competing interests}

Matthew Carroll an Editorial Board member of the Journal of Foot and Ankle Research. All other co-authors declare no competing interests.

\section{Funding}

This research received no specific grant from any funding agency.

\section{References}

1. Boulton AJ, Vileikyte L, Ragnarson-Tennvall G, Apelqvist J. The global burden of diabetic foot disease. Lancet. 2005;366(9498):1719-24.

2. Lazzarini P, Pacella RE, Armstrong D, Van Netten J. Diabetes-related lower-extremity complications are a leading cause of the global burden of disability. Diabet Med. 2018;35(9):1297-9.

3. van Netten JJ, Bus SA, Apelqvist J, Lipsky BA, Hinchliffe RJ, Game F, et al. Definitions and criteria for diabetic foot disease. Diabetes Metab Res Rev. 2020;36:e3268.

4. Armstrong DG, Boulton AJ, Bus SA. Diabetic foot ulcers and their recurrence. N Engl J Med. 2017;376(24):2367-75.

5. Reiber G, Lipsky B, Gibbons G. The burden of diabetic foot ulcers. Am J Surg. 1998;176(2):5S-10S. 
6. Bus SA, van Netten JJ. A shift in priority in diabetic foot care and research: $75 \%$ of foot ulcers are preventable. Diabetes Metab Res Rev 2016:32:195-200.

7. Gurney JK, Stanley J, York S, Sarfati D. Regional variation in the risk of lower-limb amputation among patients with diabetes in New Zealand. ANZ J Surg. 2019;89(7):868-73.

8. Ministry of Health. Annual Data Explorer 2019/20: New Zealand Health Survey [Data File] [Internet]. Ministry of Health; 2020 [cited 2021, 12/08]. Available from: https://minhealthnz.shinyapps.io/nz-healthsurvey-2019-20-annual-data-explorer.

9. Gurney JK, Stanley J, York S, Sarfati D. Lower-limb amputation in New Zealand: temporal changes and the role of diabetes mellitus. N Z Med J. 2018;131(1484):71-3.

10. Robinson TE, Kenealy T, Garrett M, Bramley D, Drury PL, Elley CR. Ethnicity and risk of lower limb amputation in people with Type 2 diabetes: A prospective cohort study. Diabet Med. 2016;33(1):55-61.

11. Gurney JK, Stanley J, Rumball-Smith J, York S, Sarfati D. Postoperative death after lower-limb amputation in a national prevalent cohort of patients with diabetes. Diabetes Care. 2018;41(6):1204-11.

12. Gurney JK, Stanley J, York S, Rosenbaum D, Sarfati D. Risk of lower limb amputation in a national prevalent cohort of patients with diabetes. Diabetologia. 2018;61(3):626-35.

13. Guz AN, Rushchitsky J. Scopus: A system for the evaluation of scientific journals. Int J Appl Mech. 2009;45(4):351.

14. Elsevier. Scopus content coverage guide [Internet]. 2020 [Available from: https://www.elsevier.com/_data/assets/pdf_file/0007/69451/Scopus_ContentCoverage_Guide_WEB.pdf.

15. Falagas ME, Pitsouni El, Malietzis GA, Pappas G. Comparison of PubMed, Scopus, Web of Science, and Google Scholar: Strengths and weaknesses. FASEB Journal. 2008;22(2):338-42.

16. Al-Busaidi IS, Abdulhadi NN, Coppell KJ. Diabetic foot disease research in gulf cooperation council countries: a bibliometric analysis. Sultan Qaboos Univ Med J. 2018;18(3):e338.

17. Johnson N, Phillips M. Rayyan for systematic reviews. J Electron Resour Librariansh. 2018;30(1):46-8.

18. Sgrò A, Al-Busaidi IS, Wells Cl, Vervoort D, Venturini S, Farina V, et al. Global surgery: a 30-year bibliometric analysis (1987-2017). World J Surg. 2019;43(11):2689-98.

19. The 2019 IWGDF Guidelines, [Internet]. 2019 [cited 202129 September ]. Available from: https://iwgdfguidelines.org/guidelines/guidelines/.

20. Oxford Centre for Evidence-Based Medicine. 2011 levels of evidence [Internet]. 2011 [cited 2021 September 13]. Available from: https://www.cebm.ox.ac.uk/resources/levels-of-evidence/ocebm-levels-ofevidence.

21. Aria M, Cuccurullo C. bibliometrix: An R-tool for comprehensive science mapping analysis. J Inform. 2017;11(4):959-75.

22. Rajamani K, Colman PG, Li LP, Best JD, Voysey M, D'Emden MC, et al. Effect of fenofibrate on amputation events in people with type 2 diabetes mellitus (FIELD study): a prespecified analysis of a randomised controlled trial. Lancet. 2009;373(9677):1780-8.

23. Dobson R, Whittaker R, Jiang Y, Maddison R, Shepherd M, McNamara C, et al. Effectiveness of text message based, diabetes self management support programme (SMS4BG): Two arm, parallel randomised controlled trial. BMJ. 2018;361.

Page $14 / 18$ 
24. Behrendt CA, Sigvant B, Szeberin Z, Beiles B, Eldrup N, Thomson IA, et al. International Variations in Amputation Practice: A VASCUNET Report. Eur J Vasc Endovasc Surg. 2018;56(3):391-9.

25. Nukada H, Van Rij AM, Packer SGK, McMorran PD. Pathology of acute and chronic ischaemic neuropathy in atherosclerotic peripheral vascular disease. Brain. 1996;119(5):1449-60.

26. Bevan WPC, Tomlinson MPW. Radiographic measures as a predictor of ulcer formation in diabetic charcot midfoot. Foot Ankle Int. 2008;29(6):568-73.

27. Misra SL, Patel DV, McGhee CNJ, Pradhan M, Kilfoyle D, Braatvedt GD, et al. Peripheral neuropathy and tear film dysfunction in type 1 diabetes mellitus. J Diabetes Res. 2014;2014.

28. Donthu N, Kumar S, Mukherjee D, Pandey N, Lim WM. How to conduct a bibliometric analysis: An overview and guidelines. J Bus Res. 2021;133:285-96.

29. King A. The New Zealand Health Strategy. Wellington: Ministry of Health. 2000.

30. Dow D. 'Medical research - Health Research Council, 1990 to 2010s' [Internet]. Te Ara - the Encyclopedia of New Zealand; [cited 2021, 17/08]. Available from: https://teara.govt.nz/mi/medical-research/page-4.

31. The Oxford Centre for Evidence-Based Medicine. The Oxford 2011 Levels of Evidence [Internet]. [cited 2021, 28/08]. Available from: http://www.cebm.net/index.aspx?o=5653.

32. Algahtani $H$, Shirah B, Boker F, Algamdi A, Alkahtani A. Neurology research in Saudi Arabia: Urgent call for action. Sultan Qaboos Univ Med J. 2017;17(3):e324.

33. Herrmann M, Sullivan DR, Veillard AS, McCorquodale T, Straub IR, Scott R, et al. Serum 25-Hydroxyvitamin $\mathrm{D}$ : A predictor of macrovascular and microvascular complications in patients with type 2 diabetes. Diabetes Care. 2015;38(3):521-8.

34. Chan KH, O'Connell RL, Sullivan DR, Hoffmann LS, Rajamani K, Whiting M, et al. Plasma total bilirubin levels predict amputation events in type 2 diabetes mellitus: The Fenofibrate Intervention and Event Lowering in Diabetes (FIELD) study. Diabetologia. 2013;56(4):724-36.

\section{Figures}



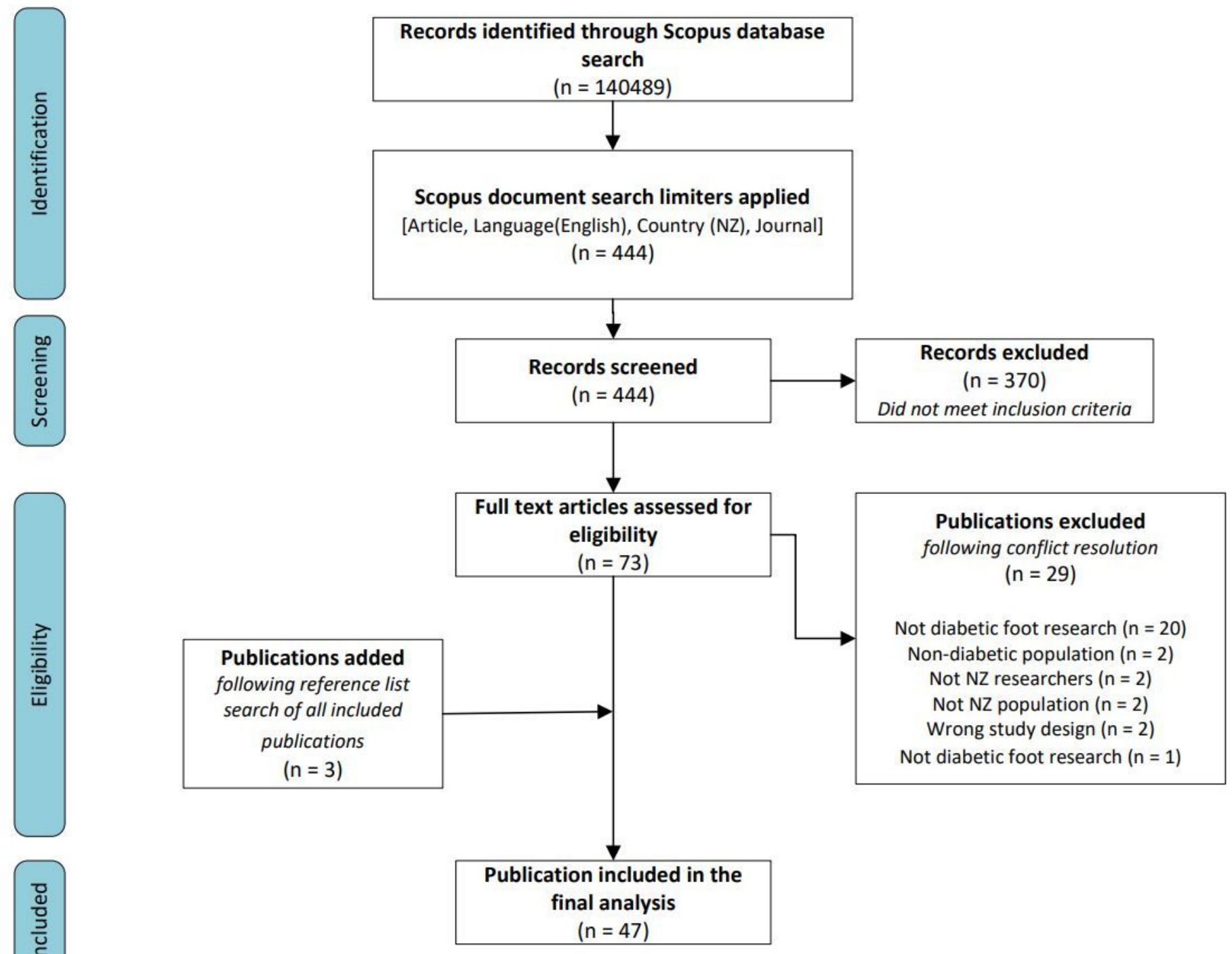

Figure 1

Flow chart for the search and retrieval process 


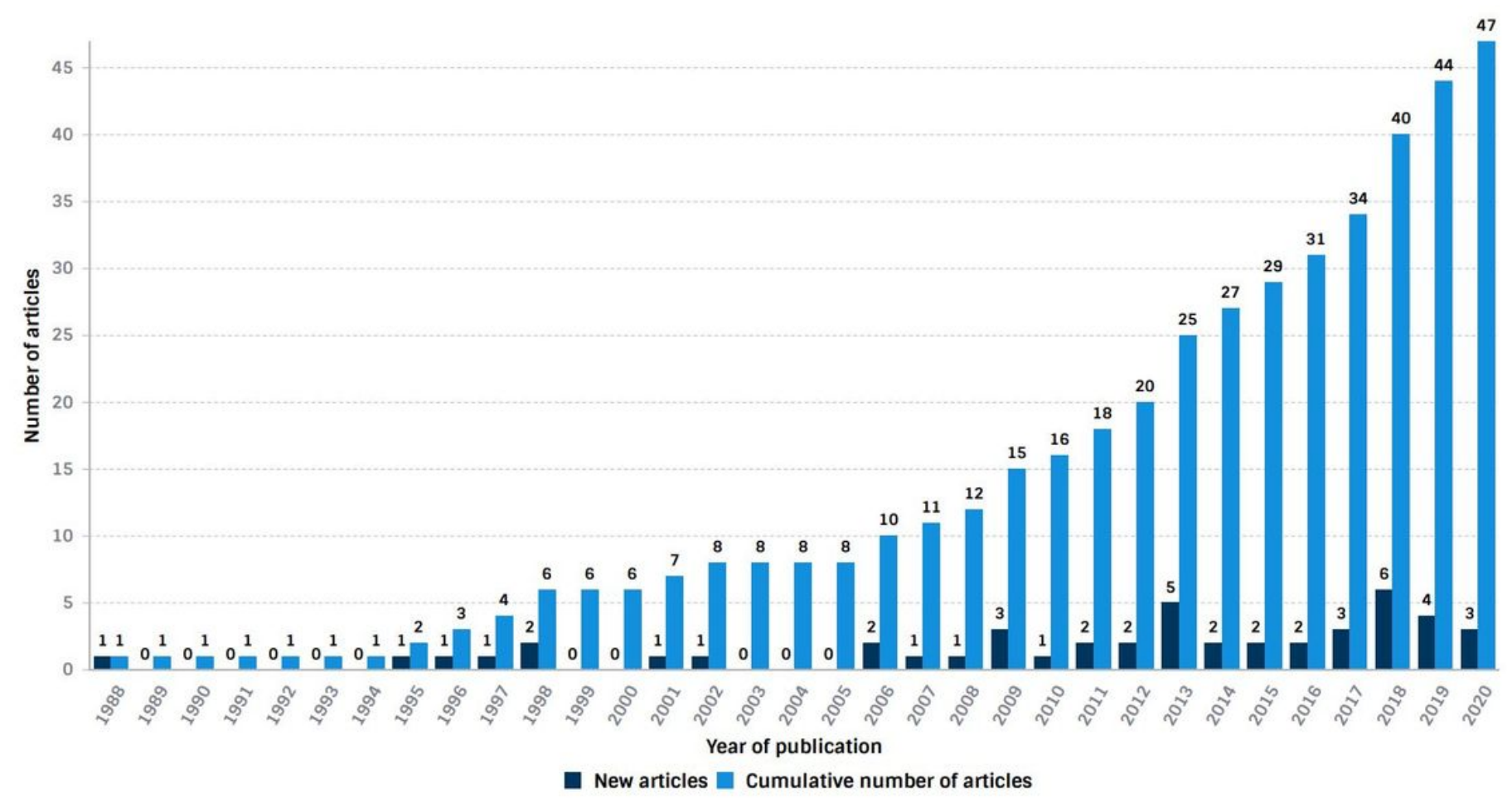

Figure 2

Graph showing the cumulative number and number of new articles of Aotearoa New Zealand diabetic foot disease-related publications per year between 1988 and 2020)

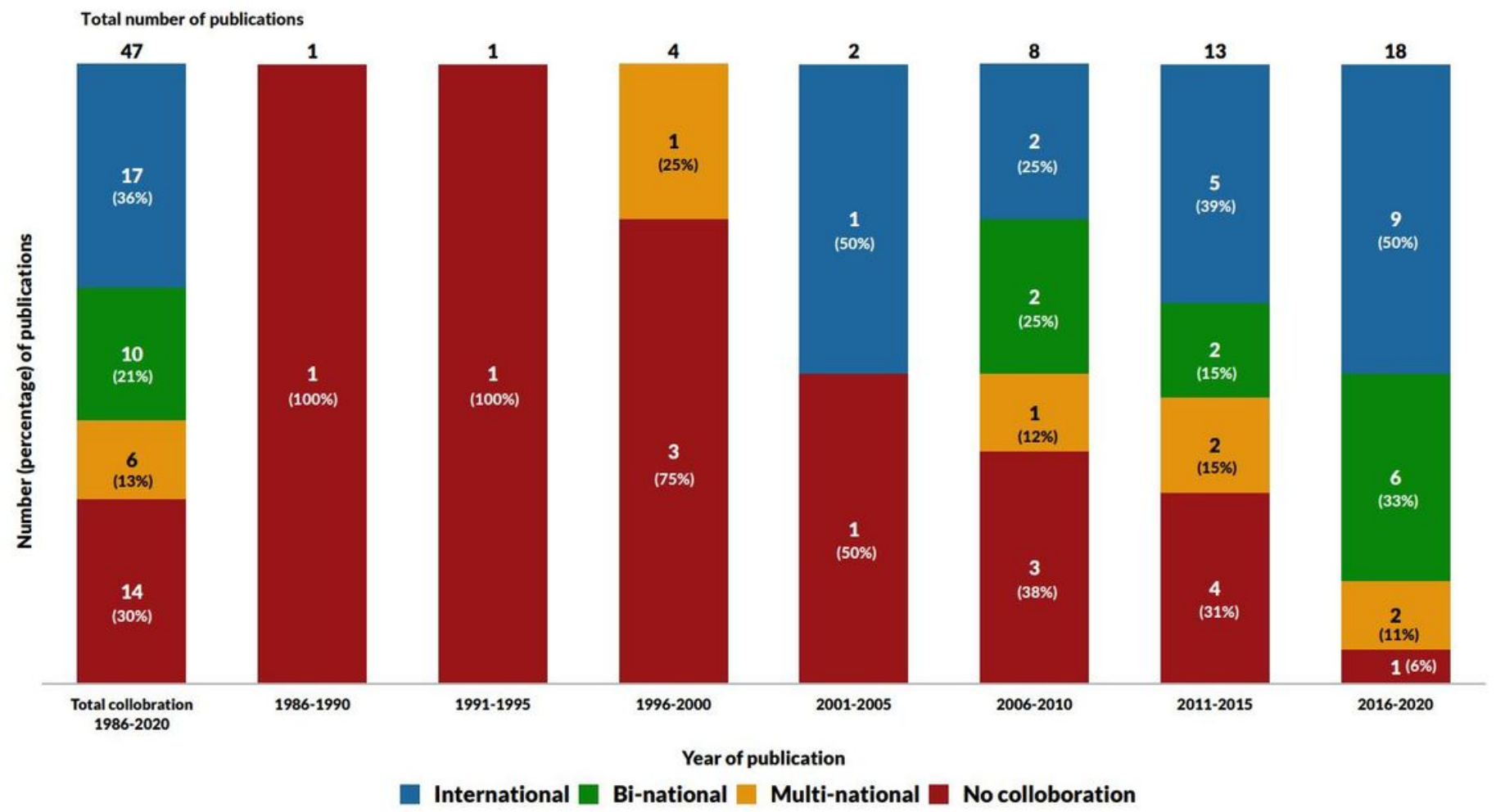




\section{Figure 3}

Graph showing authorship networks between 1986 and 2020

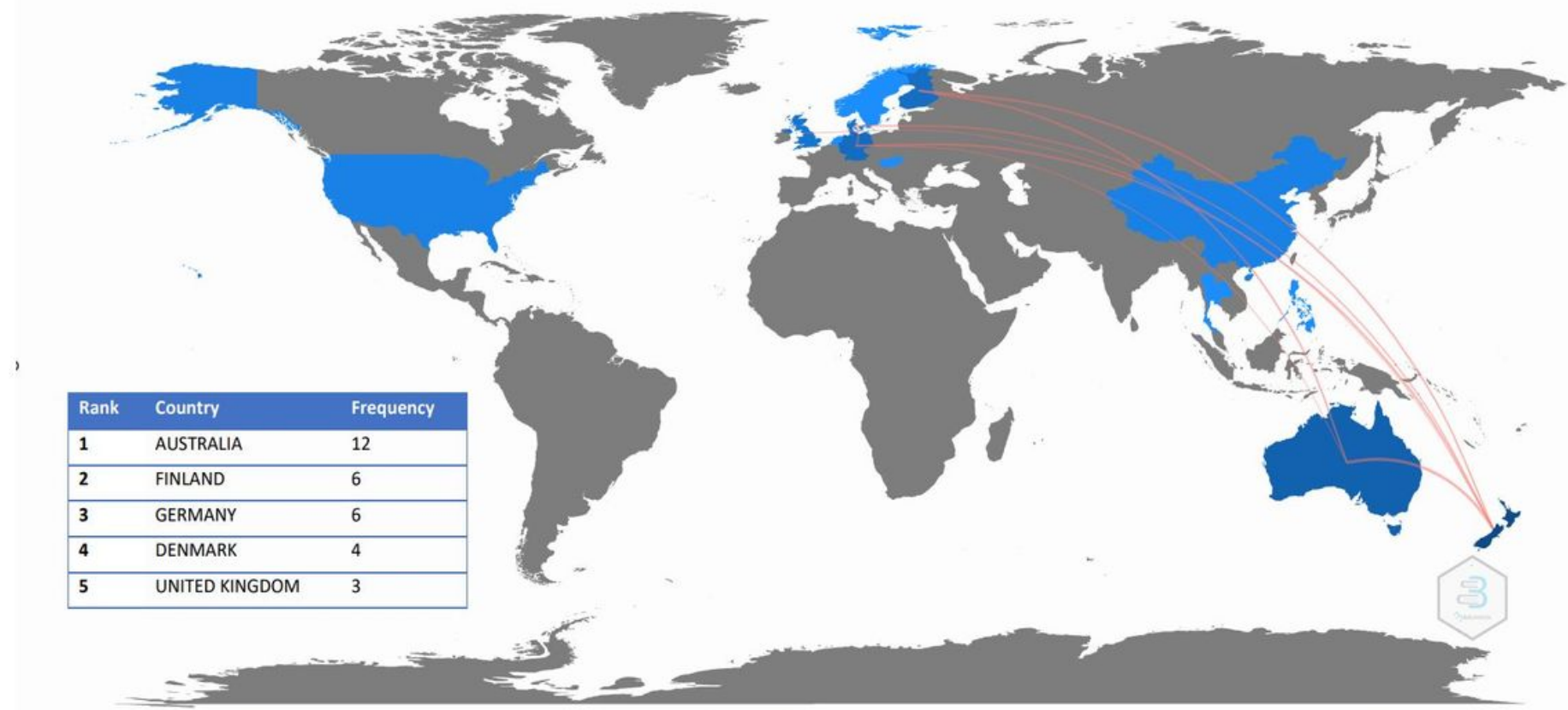

Different shade of blue indicates different rates of collaboration with NZ DFD researchers: dark blue $=$ higher collaboration; grey $=$ no collaboration . The red lines indicate countries where there were three or more research collaborations.

\section{Figure 4}

Visual representation of international collaborative authorship networks

\section{Supplementary Files}

This is a list of supplementary files associated with this preprint. Click to download.

- AdditionalFile1.pdf 